\title{
Phonological Error Patterns of Conversational Speech Produced by 2- and 4-Year-Old Children
}

\author{
Soo-Jin Kim \\ Department of Communication Disorders, Korea Nazarene University, Cheonan, Korea
}

Correspondence: Soo-Jin Kim, $\mathrm{PhD}$

Department of Communication Disorders, Korea

Nazarene University, 48 Wolbong-ro, Seobuk-gu

Cheonan 331-718, Korea

Tel: $+82-41-570-7978$

Fax: $+82-41-570-1675$

E-mail: sjkim@kornu.ac.kr

Received: January 3, 2014

Revised: February 7, 2014

Accepted: March 4, 2014

This research was supported by the Korea Nazarene University.

\begin{abstract}
Objectives: Most studies have examined the developmental error patterns of speech sounds based on elicited word productions. However, this study investigates the phonological characteristics of speech sound productions in conversational speech in 2-and 4-year-old children. The application of articulation tests for the Korean language were administered and the analyses of the phonological error patterns were conducted. Methods: A total of forty typically developing monolingual Korean children, twenty children per group in the ages of 2 and 4, who had no speech, language, hearing or cognitive problems, and participated. Speech samples were collected at the participants' homes during daily activities, including play and regular conversations with their mother. A total of 50 eojeols were analyzed. The error patterns for each age group were examined. Results: Syllable deletion, coda deletion, liquid deletion, stopping, affrication, gliding, fronting, and tensing were found in a quarter of 2-year-old children. Early phonological error patterns (syllable deletion \& word-final coda deletion) appeared to disappear by age 4 . Word-medical coda deletion, liquid deletion, stopping and tensing are found in a quarter of 4 year-old children. There were quite a few omissions and assimilations of phonemes in younger children, which appeared to be related to conversational speech as opposed to elicited word productions. Conclusion: The results depicted the early and late developmental phonological error patterns in Korean conversational speech. In addition, the clinical implication was discussed with respect to developmental speech disorders.
\end{abstract}

Keywords: Phonological error patterns, phonological processes, Speech sound development
아동의 말소리 발달 순서는 언어보편적이어서 조음동작이 단순 한 파열음과 비음이 먼저 발달하고 조음동작이 복잡한 마찰음과 유음이 나중에 발달하게 된다. 이러한 현상은 영어(Dodd, Holm, Hua, \& Crosbie, 2003; James, 2001)뿐 아니라 아랍어(Amayreh \& Dyson, 1998), 만다린(Hua \& Dodd, 2000), 캔토니즈(So \& Dodd, 1995), 한국어(Kim \& Stoel-Gammon, 2011)에서 모두 관찰된다. 이 렇게 언어권에 관계없이 유사한 패턴을 보이면서 발달하는 가장 큰 요인 중 한 가지는 말소리 산출의 해부학적 기제와 신경학적 구조 의 성장 때문이라고 할 수 있을 것이다. 일반적인 말소리 발달패턴 이 중요한 이유는 후일 말언어장애를 갖게 되는 아동을 선별하는 데 있어 중요한 정보를 제공하기 때문이다. Stoel-Gammon (1991) 은 24개월 된 아동을 음운발달에 따라서 1)전형적인 발달패턴, 2)
지체되지만 전형적인 발달패턴과 동일한 음운발달패턴, 3)음운패 턴이 전형적인 발달패턴과 다른 형태의 집단으로 나누었는데, 이 중 두 번째 집단보다 세 번째 집단이 조기중재가 더 필요하다고 조 언하고 있다. Dodd 등(2003)은 지체된 패턴과 발달적으로 다른 패 턴에 대한 보다 구체적인 기준을 제안한 바 있다. 자기 연령대의 아 동 중 $10 \%$ 이상이 사용하는 것을 나이에 적절한 오류패턴으로, 자 기 연령대의 아동 중 $10 \%$ 이하가 사용하지만 그 보다 어린 연령대 에서는 $10 \%$ 이상이 사용하는 것을 지체된 오류패턴으로, 어떤 연 령대에서도 $10 \%$ 이상의 아동이 사용하지 않는 것을 특이한 오류패 턴이라고 제안하면서 임상적으로 패턴분석의 중요성을 강조하였 다. 이러한 오류패턴은 말소리 장애를 단순한 조음문제보다는 조 음음운장애라고 하면서부터 중요한 연구문제로 대두되었으며, 아 
동이 보이는 발달적 음운현상에 대해서 음운변동, 음운패턴, 오류 패턴, 발달패턴 등 다양한 명칭으로 사용되고 있다. 음운변동이라 는 용어가 일반 음운론에서 다른 의미로 사용되고 있는 만큼, 최근 언어치료분야에서는 변동보다는 패턴이라는 용어를 선호하는 경 향이 있다(Bernthal, Bankson, \& Flipsen, 2012).

우리말과 영어는 음운 특성이 다르기 때문에 우리말 음운 특성 을 반영한 오류패턴의 연구가 필요하다. 한국어는 말소리에 유성음 은 없고 평음. 경음.격음이라는 세 가지 발성 유형이 있으며, 음절 구조 측면에서 자음군은 없고 낱말 중간에 종성과 초성의 자음연 쇄가 있다. 우리말 발성 유형의 발달과 관련하여 장애음에 파열음 의 발달과정에서 경음에 비해 음도를 낮추는 평음의 발달이 느리게 나타나는 한국어 고유의 발달적 패턴이 있음을 보여주었다(Kim, 2013; Kim \& Stoel-Gammon, 2011). 자음연쇄와 관련해서는, 초성 혹은 종성에서 자음과 연쇄되지 않는 조건에 비해 더 어려운 것을 보여주었으며(Kim, 2006), Woo와 $\operatorname{Kim}$ (2013)은 종성에서 장애음 이 올 때 공명음보다 먼저 발달한다는 것을 제시하였다.

그러나 우리말과 영어의 오류패턴의 차이를 더 크게 만드는 것은 음소 특성의 차이보다 분석에 사용되는 틀의 차이에 기인한다. 우 리 말소리 음운변동패턴을 분석하는 틀은 크게 세 가지 정도가 발 표되어 있다. $\operatorname{Kim}$ (1992), $\mathrm{Kim}$ (2006), Kim과 $\mathrm{Kim}$ (2013)의 세 가 지 음운변동 틀은 매우 다른 기준을 사용한다. Kim (1992), Kim (2006)은 단어유도 검사를 실시한 뒤 나타난 오류패턴을 분석하기 위해 설정된 틀이며, Kim과 $\operatorname{Kim}$ (2013)은 2세 아동 10명의 자발화 에서 나타난 오류패턴을 분석하여 설정한 틀이다. Kim (1992)의 틀 은 모든 오류내용을 음소의 조음방법과 조음장소에 따라 상세하 게 기술하는 형태이며, Kim과 $\operatorname{Kim}$ (2013)은 자발적 대화에서 나타 난 발달적 오류에 대해서 오류의 원인을 고려하여 간략하게 분석 하는 것이 특징이라고 할 수 있으나 아직 충분한 검증이 이루어지 지 않았다. Kim (2006)은 두 가지 틀의 중간적 형태로 발달적 오류 특징을 감안하면서 왜곡을 포함하여 조음장애 진단에 필요한 모 든 오류를 고려하였다.

음절구조변동에 대한 세 가지 틀은 음운탈락을 분석하는 기준 에 있어서도 큰 차이를 보여준다. 대표적으로 종성탈락이라는 변 동을 통해 세 가지 틀을 비교할 수 있는데 Kim (1992)의 분석 틀에 서 종성탈락을 하는 아동의 오류를 적용해본다면, 종성생략, 폐쇄 음, 유음, 비음, 양순음, 치조음, 연구개음 생략 등 일곱 가지 생략이 해당된다. 이에 비해 Kim과 $\operatorname{Kim}$ (2013)은 종성탈락을 단어 내 위 치에 따른 구분을 위주로 적용하여 어중종성탈락과 어말종성탈 락 그리고 유음탈락 세 가지로 구분하였고, $\operatorname{Kim}$ (2006)에서는 어 말종성의 탈락은 어말종성탈락이라고 구분하고, 어중종성의 탈락
은 전형적어중자음단순화(역행동화로 인한 어중종성의 동화변동 현상과 탈락현상)라고 하였다. 폐쇄음 종성은 동화되면서 탈락처 럼 실현되는 경우가 일반적이고(/책쌍/ $\rightarrow$ 챋쌍/ 혹은 /채쌍/), 비음 종성은 동화되면서 조음장소동화대치(/침대/ $\rightarrow /$ 친대/)로 실현된다. 이럴 때 폐쇄음은 동화대치인지 생략인지 판단하는 것에 어려움을 겪게 될 수 있으므로 $\operatorname{Kim}$ (2006)은 이 두 가지 현상을 모두 '전형적 어중자음단순화라고 하였다. 그러나 Kim과 Kim (2013)에서는 발 음되는 형태를 기본으로 하여 동화의 결과인지, 탈락된 것인지에 관련 없이 발음되는 형태에서 탈락된 형태로 나오면 무조건 어중종 성탈락이라고 분석하였고, 유음이 탈락되는 경우에는 유음탈락에 만 적용시켰다. 종성탈락과 함께 초성탈락에서도 세 가지 틀은 매 우 다른 형태이다. 기존의 두 가지 변동 틀(Kim, 2006; Kim, 1992) 에서는 초성탈락을 분석틀에 포함하였는데 Kim과 Kim (2013)은 초성탈락을 설정하지 않았다. 그 이유는 초성탈락이 모두 유음탈락 이라는 것이다. 다른 언어권에서의 분석(Amayreh \& Dyson, 1998; Hua \& Dodd, 2000; James, 2001; So \& Dodd, 1995)에서도 초성탈 락은 발달적으로 일반적인 현상이 아니며, 유음은 초성이나 종성 위치에 상관없이 탈락이 나타나므로, 이는 단어나 음절 내 위치 때 문이 아니고 음소 특정적인 사건이라고 그 이유를 추정한 것이다.

음운패턴 횡단연구로 우리나라에서 가장 규모가 큰 연구는 $\operatorname{Kim}$ (2006)의 취학 전 2세부터 6세까지 아동 220여명을 대상으로 한 연구이다. 2 세 아동 20 명 중 5 명 이상이 보인 음운변동 패턴을 살펴보면 전체단어변동에서는 전형적어중자음단순화(19명), 반 복/자음조화(7명), 어말종성생략(6명)으로 나타났다. 음소변화변 동에서는 마찰음과 파찰음의 파열음화(16명), 파찰음화(11명), 유 음의 단순화(유음탈락과 유음활음화를 합한 것, 8 명), 긴장음화(8 명), 연구개음 전방화(5명)로 나타났다. 이러한 오류패턴들은 3 세 와 4세가 되면서 큰 폭으로 감소하게 된다. 3-4세에 이렇게 감소되 는 것은 영어권 대규모 음운변동 연구(James, 2001)에서도 동일하 게 관찰되었다. $\operatorname{Kim}$ (2006) 연구의 4세 아동 60명에서 5명 이상이 보인 음운패턴은 치조마찰음의 치간음화(17명), 마찰음과 파찰음 의 파열음화(11명), 파찰음화(5명), 유음단순화(5명), 전형적어중자 음단순화(5명) 뿐이었다. 2 세는 20 명에서 관찰된 아동 수임에 비해 4 세는 60 명 아동에게서 관찰된 것임을 고려한다면 대단히 급격한 발달이 이루어지고 있음을 보여준 것이다.

말소리 발달에 관한 대부분의 연구들은 제한된 시간 안에 많은 아동에게 필요한 말소리와 패턴을 모두 관찰하기 쉽도록 단어유도 검사를 활용한다(Kim, 1992; Kim, 2006; Kim \& Lee, 2010). 그러나 단어유도검사 상황에서는 실제로 아동들이 일반적인 상황에서 산 출하는 다양한 어휘와 품사들이 포함되기 어려우므로 말소리 패턴 
을 평가하는 가장 타당한 문맥은 자발화임을 부인할 수 없다(Flipsen, 2006; Ha \& Hwang, 2013). 예를 들어 단어유도 검사에서 가장 배제되기 쉬운 것이 문법형태소들이다. Kim, Kim, Yoon, Chang과 Cha (2012), Choi와 Kim (2013)에서는 2세부터 4세 아동을 대상으 로 자발화 문맥에서 가장 오류가 오랫동안 나타나는 치경마찰음과 유음이 형태소 종류에 따라 다르게 발달하는지 분석하였다. 두 가 지 음소 모두 문법형태소에서는 4 세 이후에도 음운패턴이 나타나 는 것을 확인할 수 있었다. 또한 Stoel-Gammon (1987)은 보통 규준 검사를 다 수행하기 어려운 2 세 혹은 3 세 아동은 규준에서 제외된 다고 지적하면서, 일반적인 3 세 이하 아동의 말소리 발달은 자발적 인 대화 상황에서 수집 제시되어야 어린 아동들의 타당한 말소리 발달패턴을 보여줄수 있다고 하였다.

그러나 영유아의 초기 말소리 발달 단계에는 음소산출의 변이성 (variability)이 크기 때문에 2세 이전에는 음운변동분석 보다는 독 립분석이나 단어단위 음운분석 등을 통해 말소리 발달을 평가하 는 것이 적절하다. 18 개월에서 24 개월이 되어 적어도 50 단어 이상 을 사용하거나 두 단어를 조합하는 시기를 넘어서면 어느 정도 안 정된 소리의 산출이 가능해지므로 말언어진단 과정에서 음운패턴 을 분석할 수 있게 된다(Ha \& Hwang, 2013). 2세는 모국어를 습득 하는 일반적인 영유아가 발달적으로 보이는 음운오류패턴이 가장 다양하게 나타나면서 동시에 반복적으로 보여주는 최초의 연령이 기도 하다(Stoel-Gammon, 1987). 영어권에서 이루어진 음운변동 연구에서는 일반적으로 자연언어 습득과정에서 2 세부터 학령전기 까지의 아동들이 보이는 오류를 중심으로 음운변동 발달체계를 잡아왔다. 자연스럽게 이 체계를 중심으로 조음음운장애 아동의 오류 패턴이 발달적인지 비발달적인지 판단할 수 있었다.

본 연구는 어린 영유아에게 말소리를 유도할 수 있는 가장 자연 스러운 조건인 자발화 문맥에서 우리말소리 습득과정에서 나타나 는 일반적인 음운패턴을 알아보고자 한다. 안정적인 말소리 패턴이 나타나기 시작한다고 알려진 2 세의 자발화 분석을 통해 초기음운 오류패턴을 확인하고, 다시 이러한 초기 패턴이 사라지는 것으로 알려진 4세 아동을 대상으로 하여 후기까지 남아 있는 후기 음운 오류패턴을 알아보고자 하였다.

\section{연구 방법}

\section{연구대상}

이 연구의 대상은 서울과 경기 및 충남 지역에 사는 2 세와 4 세 각 각 20 명씩 총 40 명이다. 연령별 남녀비율은 2 세의 경우 $12: 8,4$ 세의 경우는 9:11이었다. 대상 아동은 1) 부모가 정상 발달을 하고 있다고
보고 하였고, 2) 우리말 조음음운 평가(UTAP: Kim \& Shin, 2004) 와3) 수용 표현 어휘력 검사(REVT: Kim, Hong, Kim, Jang, \& Lee, 2009)에서 -1 표준편차 이상으로 말언어 발달에 문제가 없고, 4) Ling Test (1976)에서 말소리를 듣는 데에 이상이 없었다.

\section{절차 및 분석}

발화수집과 전사

자발화수집 방법, 전사 및 전사 시 발화 구분 원칙은 Kim, Yoon, Kim, Chang과 Cha (2012)의 지침을 따랐다. 아동의 발화 녹음은 아동의 집에서 부모의 협조를 받아 1 주일 동안 총 10 시간 이루어졌 고, 녹음자료는 전사 훈련을 받은 연구보조원이 수행하였는데, 1 차 전사는 학부 연구보조원이, 2차 전사는 대학원생 연구보조원이 하 였다. 본 연구에서는 2 차 전사자료에서 대학원생 연구보조원이 부 모 1명과 아이의 상호작용 상황에서 연속하여 산출하는 발화를 재 선정하여 3 차 정련작업을 하였으며 이 때는 간략음성전사를 실시 하였다.

\section{분석 어절의 선정}

음운변동 분석에서는 단어를 분석의 기본 단위로 한다. 그러나 우리말과 같은 교착어의 경우 단어가 기본 단위가 되는 것은 음운 적으로 타당하지 않다고 판단하여 원칙적으로 어절을 기본 단위로 하여 연속적이지만 서로 다른 50 어절을 선정하였다. 50 어절 선정 과정에서 불명료한 어절, 바로 직전 대화 상대방의 말을 단순히 모 방한 어절, 아기 말, 감탄사, 호응발화(응, 네, 어), 외국어, 고유명사 (이름), 언어적 실수가 목표발음에 영향을 끼치는 경우는 제외하였 다. 이 논문에서 단어는 어절을 의미하며, 구체적인 기준은 Yoon, $\operatorname{Kim}$ 과 $\operatorname{Kim}(2013)$ 의 어절 기준을 따랐다.

\section{음운오류패턴 분석}

각 아동 별로 선정된 50 어절에 대해서 Appendix 1 의 음운오류패 턴 표의 해당 음운변동을 찾아 기입하였다. 아동이 산출한 단어를 비교하는 대상은 일반적인 성인의 구어형태를 목표형태로 하였다. 목표형태는 가장 단순하게 구어발음 형태로 전사된 것을 기준으로 하였다. 예를 들어 '할께'는 보통 구어로 '하께’로도 사용하므로 아 동이 ‘하께’라고 한 경우는 성인 목표형태를 ‘하께’로 하여 정조음 한 것으로 분석하였다. 기본적인 음운변동 틀은 앞에서 소개한 문 헌연구에서 나타난 발달적 음운변동을 기초로 하여 구성한 Kim과 Kim (2013)의 틀을 기본으로 하였으며, 오류 빈도가 2회 이상 관찰 된 경우는 추가하고 2 회 미만 관찰된 경우 삭제하였다. 한 어절 안 에서 두 가지 오류가 나타난 경우에는 두 개의 변동을 선택할 수 있 
지만 한 가지 오류에 대해서는 한 개의 변동을 선택하는 것을 기본 으로 하였다. 어중종성 유음을 탈락한 경우 유음탈락만 표기하고 어중종성탈락에는 표시하지 않는다.

\section{신뢰도 및 통계분석}

언어치료 전공 대학생으로 조음음운장애를 수강한 보조연구원 3 명이 함께 사전연습으로, 2 세와 4 세 연령별로 다섯 명씩의 자료를 선정하여 음소전사의 정확성과 음운패턴 분석의 정확성이 $95 \%$ 이 상의 일치를 이루도록 반복 연습을 한 후, 분석을 시작하였다. 최종 적으로 분석한 뒤에 연령별로 5 명씩 $25 \%$ 의 자료(50어절 $\times 10$ 명)를 무선적으로 선택하여 음운패턴을 분석한 결과를 비교한 결과, $98.2 \%$ 일치하였다.

각 변동에 대한 평균과 표준편차 및 관찰된 아동의 수에 대한 기 술통계치를 구하였으며 2 세와 4 세 연령 간 차이에 대하여 카이제 곱 검정을 실시하였다.

\section{연구 결과}

자발화 대화 문맥에서 20 명의 대상 아동 중 5 명 $(25 \%)$ 이상에게 서 관찰되는 자음의 고빈도 음운패턴을 나열해보면 우선 2 세 아동 은 음절구조변동에서 음절탈락, 어말종성탈락, 어중종성탈락, 유 음탈락이며, 4 세의 경우에도 어중종성탈락과 유음탈락이 평균 횟 수는 유의미하게 줄었지만 5명 이상에게서 관찰되었다. 음운대치 변동에서는 2 세 아동의 경우 고빈도 음운변동은 마찰음의 파열음 화와 파찰음화, 파찰음의 파열음화, 유음의 활음화와 파열음화, 연 구개음의 전방화와 경음화이다. 이 가운데 4 세 아동에게서도 고빈 도로 나타난 변동은 마찰음의 파열음화, 파찰음의 파열음화, 경음 화였다. 동화변동은 치경음동화만 2 세 아동에게서 빈번하게 관찰 되었다. 모음변동은 단모음화와 평순모음화가 2 세와 4 세 모두 다섯 명 이상의 아동에게서 관찰되었다. 자음의 발달적 음운패턴을 요

Table 1. Early and late developmental phonological error patterns

\begin{tabular}{ll}
\hline Early phonological pattern (2 yr) & Late phonological pattern (4 yr) \\
\hline Syllable deletion & \\
Word-final coda deletion & \\
Word-medial coda deletion & Word-medial coda deletion \\
Liquid deletion & Liquid deletion \\
Stopping (de-frication) & Stopping (de-frication) \\
Affrication (de-frication) & \\
Stopping (de-affrication) & Stopping (de-affrication) \\
Stopping (de-liquidization) & \\
Gliding & \\
Velar fronting & \\
Tensing & Tensing \\
\hline
\end{tabular}

약하면 Table 1과 같다. 구체적으로 음절구조변동, 음운대치변동, 동화변동을 살펴보고, 부가적으로 모음변동 결과를 살펴보면 다 음과같다.

\section{음절구조변동}

음절구조가 변화하는 음운패턴의 연령별 평균과 변동을 보인 아동의 수의 평균과 표준편차 및 카이제곱 검정결과는 Table 2 와 같다. 유음탈락은 음소 특정적인 것으로 보고 단어 내 위치와 음절 내 위치와 관계없이 유음탈락으로 분류하였으므로 종성탈락에서 유음탈락은 배제된 횟수이다. 2 세와 4 세 모두 유음탈락이 가장 많 았으며 다음은 어중종성탈락, 음절탈락, 어말종성의 순서이다. 네 가지 변동 모두 연령에 따라 통계적으로 유의미한 차이를 보였다. 2 세에서는 네 가지 탈락현상이 모두 열 명 이상에게서 관찰되었으 며, 4 세에서도 유음탈락은 14 명에게서 나타났고, 어중종성탈락도 20명 중 9명에게서 관찰되었다.

\section{대치변동}

연령별 대치변동 평균횟수는 Table 3 과 같다. 2 세에서 마찰음의 파열음화가 6.2 회로 가장 많았으며 다음으로 파찰음의 파열음화,

Table 2. The frequency and the number of children for deletion patterns by age

\begin{tabular}{lcccccc}
\hline \multirow{2}{*}{ Deletion } & \multicolumn{2}{c}{ Frequency } & & \multicolumn{2}{c}{ Number of children } \\
\cline { 2 - 3 } \cline { 7 - 7 } & $2 \mathrm{yr}$ & $4 \mathrm{yr}$ & & & $2 \mathrm{yr}$ & $4 \mathrm{yr}$ \\
\hline Syllable deletion & $1.85(2.03)$ & $.26(.56)$ & $8.57^{*}$ & 14 & 4 \\
Word-final coda deletion & $1.40(1.47)$ & $.10(.31)$ & $11.07^{*}$ & 13 & 2 \\
Word-medial coda deletion & $1.90(1.74)$ & $.65(.81)$ & $7.09^{*}$ & 14 & 9 \\
Liquid deletion & $3.90(2.79)$ & $1.15(.99)$ & $12.19^{*}$ & 17 & 14 \\
\hline
\end{tabular}

Values are presented as mean (SD) or number. ${ }^{*} p<.05$.

Table 3. The frequency and the number of children for substitution patterns by age

\begin{tabular}{|c|c|c|c|c|c|}
\hline \multirow[t]{2}{*}{ Substitution } & \multicolumn{2}{|c|}{ Frequency* } & \multirow[t]{2}{*}{$x^{2}$} & \multicolumn{2}{|c|}{$\begin{array}{l}\text { Number of } \\
\text { children }\end{array}$} \\
\hline & $2 \mathrm{yr}$ & $4 \mathrm{yr}$ & & $2 \mathrm{yr}$ & $4 \mathrm{yr}$ \\
\hline Stopping (de-frication) & $6.20(5.42)$ & $.65(1.42)$ & $13.29^{*}$ & 15 & 6 \\
\hline Affrication (de-frication) & $1.20(2.04)$ & $.15(.49)$ & $4.54^{*}$ & 10 & 2 \\
\hline Stopping (de-affrication) & $3.55(2.89)$ & $.60(1.57)$ & $11.59^{*}$ & 16 & 6 \\
\hline Other de-affrication & $.05(.22)$ & $.26(.93)$ & .99 & 1 & 2 \\
\hline Gliding & $.55(.89)$ & $.00(.00)$ & $6.26^{*}$ & 7 & 0 \\
\hline Nasalization (de-liquidization) & $.10(.31)$ & $.05(.22)$ & .35 & 2 & 1 \\
\hline Stopping (de-liquidization) & $.70(1.89)$ & $.15(.15)$ & $3.96^{*}$ & 8 & 2 \\
\hline Velar fronting & $1.90(3.40)$ & $.21(.54)$ & $4.18^{*}$ & 12 & 3 \\
\hline Tensing & $2.15(3.60)$ & $.75(.75)$ & 2.58 & 12 & 8 \\
\hline
\end{tabular}

Values are presented as mean (SD) or number. ${ }^{*} p<.05$. 
Table 4. The frequency and the number of children for assimilation patterns by age

\begin{tabular}{lcccccc}
\hline \multirow{2}{*}{ Assimilation } & \multicolumn{2}{c}{ Frequency } & & \multicolumn{2}{c}{ Number of children } \\
\cline { 2 - 3 } & $2 \mathrm{yr}$ & $4 \mathrm{yr}$ & & & $2 \mathrm{yr}$ & $4 \mathrm{yr}$ \\
\hline Labial assimilation & $.25(.55)$ & $.00(.00)$ & & 3.64 & 4 & 0 \\
Alveolar assimilation & $.65(.93)$ & $.05(.23)$ & $6.30^{*}$ & 8 & 1 \\
Velar assimilation & $.05(.22)$ & $.21(.54)$ & 1.50 & 1 & 3 \\
Stop assimilation & $.05(.22)$ & $.05(.22)$ & .00 & 1 & 1 \\
Other assimilation & $.15(.49)$ & $.05(.23)$ & .63 & 2 & 1
\end{tabular}

Values are presented as mean (SD) or number.

${ }^{*} p<.05$.

경음화, 연구개음의 전방화 순이었다. 4 세에 이르러서는 모두 평균 1 회 미만으로 떨어졌으나, 연구개음의 전방화가 0.8 회로 가장 높고 마찰음의 파열음화와 파찰음의 파열음화가 많이 나타났다. 2세와 4 세는 카이제곱 검정결과에서 통계적으로 마찰음의 파열음화와 파찰음화, 파찰음의 파열음화, 유음의 활음화와 파열음화, 연구개 음 전방화에서 유의미한 차이를 보였다. 2 세 아동은 절반 이상의 아동이 마찰음 파열음화, 파찰음 파열음화, 연구개음 전방화, 경음 화를 보였으며, 유음변동도 활음화, 비음화, 파열음화를 모두 합한 경우 반 이상의 아동에게서 관찰되었다. 4 세 아동은 스무명 중 다 섯명 이상이 보인 오류로 마찰음의 파열음화, 파찰음의 파열음화, 경음화가 있다.

\section{동화변동}

동화변동의 평균 발생 횟수와 아동 수는 Table 4 와 같다. 다른 문 맥에서 정조음 한다는 증거가 있는 경우에 인접한 음소의 조음장 소나 조음방법을 따라 움직인 경우에만 동화로 인정하였다. 2 세와 4 세 모두 평균 1 회 미만으로 나타났으며, 그 중에는 횟수와 아동 수 모두 치경음동화가 가장 많은 것으로 나타났다.

\section{모음변동}

연령별 모음변동은 Table 5 와 같다. 2 세 아동 절반이 복모음을 단 모음화하거나 원순모음을 평순모음화 하였으며 전반적인 평균 발 생 수는 낮지만 4세에게서도 여전히 단모음화(glide deletion)가 6 명, 평순모음화(un-rounding)가 9명 관찰되었다.

\section{논의 및 결론}

발달적 음운오류패턴을 살펴보기 위하여 2 세와 4 세의 자발화에 서 보이는 음운오류를 분류하였다. 2 세에서 자주 관찰되는 초기오 류패턴은 음절탈락, 종성탈락, 유음탈락, 마찰음·파찰음·유음의
Table 5. The frequency and the number of children for vowel process by age

\begin{tabular}{|c|c|c|c|c|c|}
\hline \multirow{2}{*}{ Vowel process } & \multicolumn{2}{|c|}{ Frequency } & \multirow{2}{*}{$x^{2}$} & \multicolumn{2}{|c|}{ Number of children } \\
\hline & $2 y r$ & $4 y r$ & & $2 \mathrm{yr}$ & $4 \mathrm{yr}$ \\
\hline $\begin{array}{l}\text { Glide deletion (diphthong } \\
\rightarrow \text { monophthong) }\end{array}$ & $1.45(1.43)$ & $.50(.89)$ & $5.58^{*}$ & 13 & 6 \\
\hline $\begin{array}{l}\text { Un-rounding (rounded } \\
\rightarrow \text { unrounded) }\end{array}$ & $1.65(1.76)$ & $.70(1.03)$ & $4.01^{*}$ & 12 & 9 \\
\hline
\end{tabular}

Values are presented as mean (SD) or number. ${ }^{*} p<.05$.

파열음화, 마찰음의 파찰음화, 활음화, 연구개음 전방화, 긴장음화, 모음변동이었으며, 4 세 이후에도 남아있는 후기오류패턴은 어중 종성탈락과 유음탈락, 마찰음-파찰음·유음의 파열음화, 연구개음 전방화와 경음화 모음변동 등이었다. 여기에서 자주 관찰된다고 하 는 기준은 분석대상자의 $25 \%$ (5명) 이상의 아동에게 관찰되었음 을 의미하지만, 평균 빈도에 있어서도 상대적으로 다른 오류패턴에 비해서 높게 나타난 변동들이다. 빈번하게 나타나는 발달패턴을 정 하는 기준은 학자에 따라 매우 다양하다. Dodd 등(2003)은 대상 중 $10 \%$ 이상의 아동이 사용하는 패턴을 빈번하다고 한 반면 본 연 구에서는 $25 \%$ 이상의 아동이 사용하는 패턴을 빈번하다고 정의하 였다. 또한 아동의 수와 함께 패턴의 사용 빈도기준을 함께 사용하 는 것도 고려할 만하다. 앞으로의 연구에서는 3 세와 5 세를 포함하 여 보다 많은 대상자의 발화를 분석하여 발달 패턴을 초기, 중기, 후 기로 분류하여 볼 필요가 있을 것이다. Park과 Kim (in press)은 기 능적 조음음운장애 아동과 조음능력을 일치시킨 일반 3 세 아동의 자발화 음운오류패턴을 비교한 결과, Table 1 에서 제시한 패턴 외 에 조음음운장애 아동은 후방화와 음소첨가를 많이 보였으며, 일 반 3 세 아동은 어중초성탈락을 많이 보인 것으로 나타났다. 발달적 음운변동 틀에는 다른 연구결과의 결과를 수용하여 어중초성탈 락을 고려해야 할 것으로 사료된다.

분석틀과 검사문맥의 차이로 $\mathrm{Kim}$ (2006)의 결과와 직접적인 비 교는 어렵지만 간접적으로 비교해볼 때 2 세의 경우 어중과 어말종 성탈락, 유음탈락, 마찰음과 파찰음의 파열음화, 활음화, 연구개음 전방화, 긴장음화가 높게 나타난 것은 유사하다. 차이가 나는 것은 본 연구결과에서 음절탈락은 빈번하다고 나타난 반면 자음조화는 덜 빈번한 것으로 나타났다. 임상적으로 볼 때에도 단어유도 상황 에서 음절탈락은 자발화 상황에 비해서 덜 관찰되는 현상으로 자 료가 수집된 문맥의 차이를 반영하는 결과라고 할 수 있을 것이다. 4세에서 빈번하게 나타나는 후기발달패턴은 어중종성탈락, 유음 탈락, 마찰음-파찰음의 파열음화, 경음화, 모음변동이었다. Kim (2006)에서도 4세 아동이 보이는 음운패턴 중 마찰음과 파찰음의 파열음화, 파찰음화, 유음탈락 혹은 활음화, 어중종성탈락 등이 빈 
-

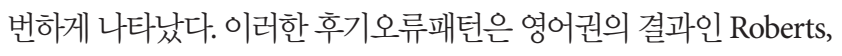
Burchinal과 Footo (1990), James (2001)가 4세 이후 5세에서도 관 찰되는 오류패턴으로 나열한 것들 중 자음군단순화나 축약을 제 외한 다른 패턴은 거의 유사한 것이다. 또 다른 차이로 연구개음의 전방화와 영어에는 없는 경음화가 늦게까지 빈번하게 관찰되었다.

본 연구에서 음운오류패턴은 크게 음절구조변동, 음운대치변동, 기타변동으로 나누어서 살펴보았다. 우선 음절구조변동에서 중요 한 발달적 오류패턴은 음절축약 및 탈락, 종성탈락, 유음탈락으로 나타났다. $\operatorname{Kim}$ 과 $\operatorname{Kim}(2013)$ 의 오류패턴분석 틀과 같이 본 연구에 서 초성탈락을 포함하지 않은 이유는 다른 언어권에서의 분석에서 도 자발화를 분석대상으로 할 때 어두초성(word initial) 탈락은 발 달적으로 나타나지 않으며(Bernthal et al., 2012), 2 세와 4세의 자발 화에서 나타난 모든 초성탈락이 유음탈락이었으므로 유음이라는 음소 특정적 사건으로 추리하였기 때문이다. 음절탈락과 어말종성 탈락은 2 세에서 평균 1 이상의 높은 빈도를 보이다가 4 세에서 급격 하게 줄어들었다. 어중종성탈락과 유음탈락은 2 세와 4 세 모두 높 은 빈도를 보였으며 특히 4 세 집단에서도 9 명, 14 명에게서 관찰될 정도로 많은 아동이 오류를 보였다. 그러나 네 가지 탈락현상 모두 카이제곱 검정에서 유의미한 차이를 보여 연령에 따라 뚜렷하게 변 화되는 것을 보여주었다.

유음탈락은 2 세와 4 세 모두 높은 빈도로 나타났는데 음소 특정 적인 사건으로 본다는 것은 대치변동인 탈유음화와 유음탈락을 함께 살펴볼 필요가 있음을 의미한다. 유음의 대치변동 중 활음화 와 파열음화를 보인 아동의 숫자를 비교한 결과도 흥미롭다. 활음 화는 2 세에서 7 명이 보이지만 4 세에서 단 한 명도 보이지 않았다. 그러나 파열음화는 2 세에서 8 명의 아동이 보였으며 4 세에도 여전 히 2 명의 아동에게서 관찰되었다. 초기에는 유음의 파열음화보다 활음화가 빈번하지만 후기에는 파열음화보다 활음화가 관찰되지 않은 것이다.

대치변동에서 2 세와 4 세가 통계적으로 유의미한 차이를 보인 오 류패턴은 세 가지 종류(마찰음, 파찰음, 유음)의 파열음화, 그리고 마찰음의 파찰음화, 유음의 활음화, 연구개음의 전방화였다. 조음 방법측면에서 난이도가 높은 마찰음, 파찰음, 유음은 초기에 발달 하는 보다 쉬운 조음방법인 파열음으로 대치되어 나타나는 것이 일반적인 패턴이다. 2 세의 자발화에서도 이 현상은 두드러지게 나 타났으며 오류 빈도 평균은 마찰음이 6.2회, 파찰음이 3.6회, 유음 이 0.7 회로 차이를 보였다. Kim (2006)은 마찰음과 파찰음에서 치 찰성 자질이 산출되지 않는다는 공통점 때문에 두 가지 음소의 파 열음화를 같은 현상으로 보았는데, 이렇게 보는 것은 영어권 아동 의 오류패턴 분석에서도 일반적인 방법이다(Bernthal et al., 2012).
그러나 $\operatorname{Kim}$ (2006), Choi와 Kim (2013)도 지적했던 바와같이 우리 나라 아동의 분석과정에서 유음이 초성이 되는 경우 탄설음으로 실현되면서 파열음화가 빈번하게 나타난다. 따라서 본 연구결과에 서는 세 가지 파열음화를 하나의 파열음화로 보지 않고, 진단과 치 료상황에서 임상가들은 편의에 따라 세 개의 목표음소가 파열음 화 되는 현상을 묶거나 나누어 볼 수 있도록 목표음소 형태별로 나 누어 제시하였다. 마찰음과 파찰음의 파열음화는 2 세는 각각 15 명, 16 명에게서 관찰되었을 뿐 아니라 4 세 아동에서도 각각 6 명씩에게 서 나타났다. 이 결과는 자발화에서 오류패턴이 사라지는 연령을 연구하기 위해서는 만 5 세, 6 세 이후까지 확장하여 연구해야 할 필 요성을 보여준 것이다. 마찰음의 파찰음화는 4세에 이르면 $10 \%$ 이 하인 2 명에게서만 나타났다.

연구개음 전방화와 경음화는 2 세에서 각각 12 명에게서 관찰된 빈번한 오류패턴이었다. 4 세에서 연구개음 전방화는 3 명의 아동에 게서만 관찰되고 오류빈도 역시 통계적으로 유의미한 차이가 날 정 도로 발달되었다. 경음화는 4 세에서도 8 명의 아동에게서 관찰되었 으며, 오류빈도 역시 약간 줄었지만 통계적으로 두 집단 간에 유의 미한 차이를 보이지 않았다. 경음화는 발성유형의 문제로 영어권 음운변동 발달 연구에서는 유성성 실현의 문제와 비교해볼 수도 있겠지만, 긴장성과 기식성이라는 두 가지 자질의 실현과 관련된 우 리말 특정적인 오류패턴이라고 할 수 있을 것이다.

동화변동은 다른 연구들에 비해 매우 낮은 빈도로 관찰되었다. 연령별로 차이를 보인 변동은 치경음동화로 2 세 아동 8 명에서, 오 류빈도는 평균 0.65 회 관찰되었으나 4 세 아동 1 명에게서만 관찰되 었다. 분석과정에서 목표음소가 분석하는 어절 이외의 다른 어절 에서 정조음된 증거가 있는 경우에 국한하여 대치가 아닌 동화로 분류하였다. $\operatorname{Kim}(2006)$ 은 자음조화와 어중자음연쇄 단순화라는 이름으로 어절과 음절내 위치를 고려하여 동화를 나누거나 묶어서 살펴보았고, $\operatorname{Kim}$ (1992)은 모든 조음방법과 조음위치에로 나누어 살펴보았다. 영어권 아동에서도 동화변동은 비교적 초기에 사라지 는 변동임을 고려할 때(Grunwell, 1981), 우리말에서도 자발화 문맥 에서는 일부 동화변동은 대치나탈락에 비해 초기에 사라지는 변동 일 수도 있다고 추론된다. 그러나 $\operatorname{Kim}$ (2006), Woo와 Kim (2013) 에서 따로 살펴본 바와 같이 어중종성탈락은 어중종성의 역행동 화와 같은 현상으로 볼 수 있으며, 어중종성탈락이 4세 이후에도 빈번하게 관찰되는 것으로 볼 때 역행동화는 발달적으로 후기까지 남는 오류임이 분명하다.

대부분의 음운변동 분석에서는 모음을 분석하지 않는다. 그러나 자발화에서 매우 빈번할 뿐 아니라 연령별 차이를 보여줄 수 있는 것으로 나타나서 본 연구에서는 모음변동을 포함하였다. 분석과정 
에서 일반적인 성인들의 패턴을 보이는 경우는 오류로 하지 않았 다. 예를 들어 활음 $/ \mathrm{w} /$ 계열 복모음은 자발화 문맥에서 많은 경우 활음이 탈락되어 단모음으로 산출되기 때문에 활음/ $/$ /를 생략한 경 우에만 단모음화로 분류하였다. 또한 원순모음이 평순모음화되는 경우에도 어말에서/해요/가/해여/가 되는 등의 일상적인 수준의 성인패턴과 유사한 경우에는 정조음이라고 보았다. 이러한 경우를 모두 배제하였음에도 2 세에서는 단모음화와 평순모음화가 각각 13 명, 12 명에게서 관찰되었으며, 4 세에도 각각 6 명, 9 명에서 관찰되었 다. 또한 산출빈도 평균에서도 두 집단 간 통계적으로도 유의미한 차이를 보였다. 청각장애가 있는 경우와 같이 말소리 산출장애의 특정 원인에 따라 비발달적인 모음 오류패턴을 보일 수 있다(Do \& $\mathrm{Kim}, 2004)$. 이 연구에서 나온 결과는 자발화를 분석하는 과정에 서 발달적인 모음오류 패턴의 준거로, 다른 말소리 장애 영역에서 나타나는 오류패턴과도 비교해볼 필요가 있다. 청각장애를 포함하 여 다양한 말소리 장애의 원인별 중증도별로 자발화에서의 음운 오류패턴 연구가 필요하다.

자발화 평가를 임상에 적용할 때 가장 큰 한계점으로 지적되는 것이 임상현장에서 관찰하고자 하는 모든 음소목록과 음운현상 이 나오지 않을 수 있다는 것이다. 일단 아동은 자신의 목록에 없는 음소나 음운현상이 포함된 낱말을 사용하지 않는 경우가 많다. Choi와 Kim (2013)에 나타난 유음 변동을 살펴보면 종성 설측음 은 생략, 활음화, 비음화, 파열음화 순서로 공명이 큰 순서로 변동이 나타나면서 생략의 비중이 압도적인 반면, 어중초성 탄설음은 활 음화가 가장 많이 나타나고 다음으로 생략과 파열음화, 비음화가 고르게 나타나는 양상을 보였으나 본 연구에서는 생략이 압도적이 고 다음으로 파열음화, 활음화가 나타나서 이전 연구의 설측음 오 류패턴과 유사한 양상을 보였다. 발달적으로 후기음소인 탄설음이 연속발화에서 선정된 50어절에 많이 포함되지 않았기 때문일 수 있다. 이러한 결과는 자발화 분석의 경우 대상이 되는 인원과 발화 의 양 및 분류 기준 등에 따라 오류패턴과 빈도에 차이가 있을 수 있음을 시사하는 것이다.

본 연구의 의의는 다음과 같이 네 가지로 요약할 수 있다. 첫째로 는 3세 미만의 어린 아동을 대상으로 음운변동을 관찰할 수 있는 가장 이상적이고 자연스러운 구어 환경인 대화문맥에서 발달적인 음운변동 패턴을 분석하였다는 점이다. 두 번째로는 아동의 발화 형태와 비교하는 성인의 목표형태를 표준어가 아닌 최대한 자연스 러운 구어형태와 비교하였다는 점에서 이전의 연구들과 차별화 될 수 있다. 세 번째로는 음운변동의 종류를 간략하게 하여 임상에서 발달적 음운변동 패턴의 확인을 용이하도록 했다. 본 연구 결과와 이전 연구결과에 대한 문헌연구들을 토대로 한 발달적 음운오류패
턴을 정리하여 Appendix 2에 제시하였다. 본 연구에서 채택한 음 운오류패턴의 명칭은 음성학적 현상만을 근거로 간략하게 음운변 동을 요약해주는 동시에, 최대한 음운론적 현상의 원인을 추정할 수 있도록 고려한 것이다. 이러한 분석기준은 자발화의 발달적 음 운오류분석 틀로 활용할 수 있을 것으로 기대된다. 네 번째로 전형 적인 발달 과정을 보이는 조음장애 아동을 대상으로 음운론적 치 료접근을 시도할 때, 초기음운패턴과 후기음운패턴으로 치료목표 의 순서를 설정하는 데 지침을 제공하였다. 치료 순서를 정하면서 고려할 수 있는 변수인 난이도, 빈도 등에 대한 이론적 발달적 근거 로 삼을수 있기 때문이다.

\section{REFERENCES}

Amayreh, M. M., \& Dyson, A. T. (1998). The acquisition of Arabic consonants. Journal of Speech, Language, and Hearing Research, 41, 642-653.

Bernthal, J. E., Bankson, N. W., \& Flipsen, P. (2012). Articulation and phonological disorders (7th ed.). Boston, MA: Pearson.

Choi, M. S., \& Kim, S. J. (2013). Morphological influences on liquid acquisition in korean children's spontaneous speech. Communication Sciences \& Disorders, 18, 76-85.

Do, Y., \& Kim, S. (2004). Comparisons of utility of various speech intelligibility evaluations of adults with hearing impairment. Korean Journal of Speech Sciences, $11,173-184$.

Dodd, B., Holm, A., Hua, Z., \& Crosbie, S. (2003). Phonological development: a normative study of British English-speaking children. Clinical Linguistics \& Phonetics, 17, 617-643.

Flipsen Jr, P. (2006). Measuring the intelligibility of conversational speech in children. Clinical Linguistics \& Phonetics, 20, 303-312.

Grunwell, P. (1981). The development of phonology: a descriptive profile. First Language, 2, 161-191.

Ha, S., \& Hwang, J. (2013). Speech measures from phonological analyses of spontaneous conversation in children between 18-47 months of age. Communication Sciences \& Disorders, 18, 425-434.

Hua, Z., \& Dodd, B. (2000). The phonological acquisition of Putonghua (modern standard Chinese). Journal of Child Language, 27, 3-42.

James, D. G. (2001). Use of phonological processes in Australian children ages 2 to 7;11 years. International Journal of Speech-Language Pathology, 3, 109127.

Kim, J. M., Yoon, M. S., Kim, S. J., Chang, M. S., \& Cha, J. (2012). Utterance Types in Typically Developing Preschoolers. Korean Journal of Communi- 
cation Disorders, 17, 488-498.

Kim, M. J. (2006). The phonological error patterns of preschool children in the 'Korean Test of Articulation for Children'. Korean Journal of Communication Disorders, 11, 17-31.

Kim, M. J. (2013). The developmental aspects of phonetic contrast of Korean word-initial stops in young Korean children. Communication Sciences \& Disorders, 18, 417-424.

Kim, M., \& Stoel-Gammon, C. (2011). Phonological development of wordinitial Korean obstruents in young Korean children. Journal of Child Language, 38, 316-340.

Kim, S. J., \& Lee, S. (2010). A comparison of Korean articulation tests for evaluation of phonological disorders. Special Education Research, 10, 343-359.

Kim, S. J., Kim, J. M., Yoon, M. S., Chang, M. S., \& Cha, J. (2012). Alveolar fricative sound errors by the type of morpheme in the spontaneous speech of 3- and 4-year-old children. Journal of the Korean Society of Speech Sciences, 4, 129-136.

Kim, S., \& Kim, M. (2013). Phonological characteristics of conversational speech produced by young Korean children. Annual Convention of the American Speech Language Hearing Association, Chicago, IL.

Kim, Y. T. (1992). A study of phonological regression in 2-6 years of Korean children. Malsori, 21, 3-24.

Kim, Y. T., \& Shin, M. J. (2004). Urimal Test of Articulation and Phonology (U-TAP). Seoul: Hakjisa.

Kim, Y. T., Hong, G. H., Kim, K. H., Jang, H. S., \& Lee, J. Y. (2009). Receptive
\& expressive vocabulary test (REVT). Seoul: Seoul Community Rehabilitation Center.

Ling, D. (1976). Speech and the hearing-impaired child: theory and practice. Washington, DC: Alexander Graham Bell Association for the Deaf.

Park, K., \& Kim, S. J. (in press). Phonological error patterns in the spontaneous speech of Korean children with functional articulation disorders. Proceedings of Spring Convention of the Korean Society of Speech Sciences, Chuncheon, Korea.

Roberts, J. E., Burchinal, M., \& Footo, M. M. (1990). Phonological process decline from 212 to 8 years. Journal of Communication Disorders, 23, 205217.

So, L. K., \& Dodd, B. J. (1995). The acquisition of phonology by Cantonesespeaking children. Journal of Child Language, 22, 473-496.

Stoel-Gammon, C. (1987). Phonological Skills of 2-Year-Olds. Language, Speech, and Hearing Services in Schools, 18, 323-29.

Stoel-Gammon, C. (1991). Normal and disordered phonology in two-yearolds. Topics in Language Disorders, 11, 21-32.

Woo, H., \& Kim, S. (2013). Coda sounds acquisition at word medial position in three and four year old children's spontaneous speech. Journal of the Korean Society of Speech Sciences, 5, 78-81.

Yoon, M. S., Kim, S. M., \& Kim, S. J. (2013). Phonological whole-word measures of spontaneous speech in 2-4 years of age. Korean Journal of SpeechLanguage \& Hearing Disorders, 22, 69-85. 
Appendix 1. 음운오류패턴

\begin{tabular}{lll}
\hline 음절구조변동 & 대치변동 & 동화변동 \\
\hline 음절탈락 & 마찰음 파열음화 & 양순음동화년동 \\
어말종성탈락 & 마찰음 파찰음화 & 치경음동화 \\
어중종성화탈락 & 파찰음 파열음화 & 연구개음동화 \\
유음탈락 & 파찰음 기타변동 & 파연모음음황화 \\
& 유음 활음화 & 기타동화 \\
& 유음 비음화 & \\
& 유음 파열음화 & \\
& 연구개음 전방화 & \\
& 경음화 & \\
& &
\end{tabular}

Appendix 2. 발달적 음운오류패턴 해설

I. 음절구조 변동

\begin{tabular}{lll}
\hline 분류 & \multicolumn{1}{c}{ 설명 } & 예 \\
\hline 1. 음절탈락 & 축약 혹은 음절 생략 & 하비/하라버지 \\
2. 어중초성탈락 & 어중초성의 생략(유음 제외) & 머으면/머그면 \\
3. 어중종성탈락 & 어중종성의 생략(유음 제외) & 어떠/업써 \\
4. 어말종성탈락 & 어말종성의 생략(유음 제외) & 우도/우동 \\
5. 유음탈락 & 초성에서 탄설음 생ㄹㅑㅑ & 이어케/이러케 \\
& 종성에서 설측음 생략 & 힌바/신발 \\
\hline
\end{tabular}

II. 음운대치 변동

\begin{tabular}{|c|c|c|c|}
\hline 분류 & 소분류 & 설명 & 예 \\
\hline 1. 탈유음화 & $\begin{array}{l}\text { 활음화 } \\
\text { 비음화 } \\
\text { 파열음화 }\end{array}$ & $\begin{array}{l}\text { 유음이 활음으로 산출 } \\
\text { 유음이 비음으로 산출 } \\
\text { 유음이 파열음으로 산출 }\end{array}$ & $\begin{array}{l}\text { 바요/바로 } \\
\text { 호낭이/호랑이 } \\
\text { 때뎌/때려 }\end{array}$ \\
\hline 2. 탈마찰음화 & $\begin{array}{l}\text { 파열음화 } \\
\text { 파찰음화 } \\
\text { 기타 }\end{array}$ & $\begin{array}{l}\text { 치경마찰음이 파열음으로 산출 } \\
\text { 치경마찰음이 파찰음으로 산출 } \\
\text { 치경마찰음의 조음장소가 전후방으로 이동되어 산출(왜곡포함) }\end{array}$ & $\begin{array}{l}\text { 업떠요/업써요 } \\
\text { 체명이야/세명이야 } \\
\text { 헤개, } \theta \varepsilon g \varepsilon, \int \varepsilon g \varepsilon / \text { 세개 }\end{array}$ \\
\hline 3. 탈파찰음화 & $\begin{array}{l}\text { 파열음화 } \\
\text { 기타 }\end{array}$ & $\begin{array}{l}\text { 파찰음이 파열음으로 산출 } \\
\text { 파찰음이 파열음 외 음소로 산출 }\end{array}$ & $\begin{array}{l}\text { 마니도/마니조(많이 줘) } \\
\text { 후카함니다/추카함니다 }\end{array}$ \\
\hline 4. 연구개음 전방화 & & 연구개음의 조음장소가 앞으로 이동되어 치경음 혹은 경구개음으로 산출 & 여디떠/여기써 \\
\hline 5. 평음과 격음의 경음화 & & 평음과 격음이 경음으로 산출 & 이찡/이층 \\
\hline
\end{tabular}

III. 기타 (동화/모음변동)

\begin{tabular}{|c|c|c|c|}
\hline 분류 & 소분류 & 설명 & 예 \\
\hline 1. 순행동화* & & 앞소리가 뒤에 오는 소리의 영향으로 같게 혹은 유사하게 산출 & $\begin{array}{l}\text { 고꾸잠따디/고추잠자리 } \\
\text { 채찬/책쌍 }\end{array}$ \\
\hline 2. 역행동화* & & 뒷소리가 앞 소리의 영향으로 같게 혹은 유사하게 산출 & $\begin{array}{l}\text { 지차/기차 } \\
\text { 샌지/생쥐 }\end{array}$ \\
\hline 3. 모음변동 & $\begin{array}{l}\text { 단모음화 } \\
\text { 평순모음화 }\end{array}$ & $\begin{array}{l}\text { 활음'I(j)'를 생략하고 산출 - 활음 ' } T(\mathrm{w} \text { )'생략하는 경우(전하/전화, 게물/괴물)는 제외 } \\
\text { 원순모음이 평순모음으로 산출 }\end{array}$ & $\begin{array}{l}\text { 그어먼/그러면 } \\
\text { 저아여/조아요 }\end{array}$ \\
\hline
\end{tabular}

*동화는 목표음소가 다른 문맥에서 정조음으로 산출되는 증거가 있는 경우에 국한. 


\section{국문초록}

\section{자발화에 나타나는 발달적 음운오류패턴}

\section{김수진}

나사렛대학교 언어치료학과

배경 및 목적: 말소리 습득과정에서 나타나는 정상적인 음운오류패턴을 알아보기 위해 가장 타당한 문맥은 자발화이다. 문헌고찰을 통해 안정적인 말소리 패턴이 나타나기 시작한다고 알려진 2세의 자발화 분석을 통해 초기음운오류패턴을 확인하고, 다시 이러한 초기 패턴이 사라지는 것으로 알려진 4세 아동을 대상으로 하여 후기까지 남아 있는 후기 음운오류패턴을 알아보고자 하였다. 방법: 2 세와 4 세 각 집단 별로 20 명씩 총 40 명의 자발화에서 50 어절씩을 추출하여 음운변동을 구하고 각 변동 별 집단 간 차이를 검정하였다. 결과: 2 세에서 주로 관찰되는 초기오류패턴은 음절탈락, 종성탈락, 유음탈락, 마찰음-파찰음-유음의 파열음화, 마찰음의 파찰음화, 활음화, 연구개음 전방화, 긴장음화였으며, 4 세 이후에도 남아있는 후기오류패턴은 어중종성탈락과 유음탈락, 마찰음 - 파찰음의 파열음화, 연 구개음 전방화와 경음화 등이었으며 유음탈락과 어중종성탈락, 마찰음의 파열음화와 경음화였다. 논의 및 결론: 본 연구는 자발화 문 맥에서 적용하기에 편리하도록 고안된 발달적 음운변동 분석의 기본적인 준거 틀을 검증하였으며, 자발화에서 나타나는 초기와 후기 음운오류패턴의 발달적 비교 준거를 제공하였다. 단어유도 문맥에서 나온 이전 연구들에 비해 자발화에서 유도한 결과 음소탈락과 동 화가 적게 나타났다. 이 연구의 결과는 말소리장애아동의 자발화를 통한 음운 진단과정에서 나타나는 오류가 발달적 오류패턴특성인 지 판단하는 것과, 음운치료목표를 수립하는 데 이용될 수 있을 것이다.

핵심어: 음운변동, 오류패턴, 자발화, 음운발달 말소리 습득

이 연구는 나사렛대학교 연구비 지원에 의하여 수행되었음.

\section{참고문헌}

김민정(2006) ‘아동용 조음검사'에 나타난 취학 전 아동의 음운 오류패턴. 언어청각장애연구, 11, 17-31.

김수진, 김정미, 윤미선, 장문수, 차재은(2012). 자발화에 나타난 3-4세 아동의 형태소 유형별 치경마찰음 발달 특성. 말소리와음성과학, 4, 129-136. 김수진, 이수향(2010). 음운장애 평가를 위한 한국어 검사 비교. 특수교육, 10, 343-359.

김영태(1992). 서울-경기 지역 2- 6세 아동의 발달기적음운변동에 관한 연구. 말소리, 21, 3-24.

김영태, 신문자(2004). 우리말 조음음운 평가 (U-TAP). 서울: 학지사.

김영태, 홍경훈, 김경희, 장혜성, 이주연(2009). 수용·표현어휘력검사(REVT). 서울: 서울장애인종합복지관.

김정미, 윤미선, 김수진, 장문수, 차재은(2012). 학령전기 일반아동의 발화유형과 발화 종결기능 어미 사용 특성. 언어청각장애연구, 17, 488-498. 도연지, 김수진(2004). 청각장애 성인의 말명료도 평가방법의 비교. 음성과학, 11, 173-184.

박가연, 김수진(출판중). 기능적 조음음운장애 아동의 자발화음운오류패턴 분석. 한국음성학회 봄 학술대회. 춘천.

우혜경, 김수진(2013). 자발화에 나타난 3-4세 아동의 어중종성 습득. 말소리와음성과학, 5, 78-81.

윤미선, 김정미, 김수진(2013). 자발화 문맥에서의 단어단위 음운평가: 2-4세 아동 대상. 언어치료연구, 22, 69-85.

최민실, 김수진(2013). 자발화에 나타난 3-4세 아동의 형태소 유형별 유음 발달 특성. Communication Sciences and Disorders, 18, 76-85.

하승희, 황진경(2013). 18-47개월 아동의 자발화 분석에 기초한 말소리 측정치에 관한 연구. Communication Sciences and Disorders, 18, 425-434. 